\title{
Development of a Tourism Village Based on the Integration of Language Education and Local Potential (Case Study in Karanganyar Regency, Central Java, Indonesia)
}

\author{
Agung Wibowo ${ }^{1, *}$ Dimas Rahadian Aji Muhammad ${ }^{1}$, Eny Lestari ${ }^{1}$, Ravik $_{\text {Karsidi }}{ }^{2}$ \\ ${ }^{1}$ Faculty of Agriculture, Universitas Sebelas Maret Jl. Ir. Sutami 36 A, Surakarta, Indonesia \\ ${ }^{2}$ Doctoral Program in Development Exstension, Graduate School, Universitas Sebelas Maret, Jl. Ir. \\ Sutami 36 A, Surakarta, Indonesia
}

\begin{abstract}
The development of Language Education Tourism destinations in Karanganyar Regency is a model that can be used for developing tourism villages in Indonesia. The goal of the research is to discover how language education is able to become a tourist attraction and boost the local economy. The research method is qualitative and uses a case study approach to explore how language education is integrated with local potential to create a model for the development of a tourism village. In a case study, data collection includes various sources, such as observation, interviews, FGDs, audio visual material, documents, and reports. Informants in this study were local communities, village officials, leaders of Isy Karimah Islamic boarding schools, head of tourism village development associations, the young people's organization (Karang Taruna), souvenir craftsmen, local financial institutions. Data analyzed by interactive analysis. The research results show that the integration of education of three languages (Arabic, English, and Javanese) with local potential (art, culture, agriculture, and stockbreeding) is an important entity in developing the local economy. The integration of the education of these three languages with local potential is found in a number of destinations of tourism villages.
\end{abstract}

\section{Introduction}

Tourism for community development is not a new agenda. The concept and approach of community based tourism development are conceptualized as an alternative strategy to the conventional mass tourism model. This alternative approach has been designed to create a sustainable tourism industry in numerous locations throughout the world, thereby improving the local living conditions, with a long-lasting effect, and ultimately, encouraging sustainable community development [1]. Furthermore, states that in

\footnotetext{
*Corresponding author: agungwibowo@staff.uns.ac.id
} 
community capacity building, it is necessary to carry out transformation at the level of human awareness, to move from a naive, magical awareness towards a critical awareness [2]. This critical awareness will subsequently make local communities realize that they have a huge potential to attract tourists, through their traditions, cultures, or the beauty and uniqueness of their natural surroundings [3, 4].

Ideally, the development of a tourism village is the development of an area that has the ability to empower the local community and is based on the potential of natural and environmental resources in that area, but in reality, the development of tourism villages taking place at the present time is not always in line with the wishes of the surrounding community. Some of the common problems are poor wages and unhealthy work conditions. Frequently, this negative externality originates from irresponsible business practices implemented by tourism companies [5]. The negative externality specific to industries is often rooted in the capitalist approach adopted in the development model of conventional 'mass tourism'. In this scheme of development, investors are encouraged to exploit local resources for profit oriented activities which may eliminate the access of local residents to these assets. This article will describe the development of a tourism village that integrates language education and local potential.

Education is a process which aids human development, or in other words humanizes human beings. Education helps people to perfect themselves as human beings [6]. Human beings are God's creatures who were born with the potential to be educated as well as to educate, thus enabling them to become caliphs on earth, supporters and developers of culture. According to Ibn Khaldūn [7], the true essence of human beings is as God's servants and representatives on earth, creatures created by God with full potential, complete with the senses of hearing, sight, and reason, enabling them to become pure intellectuals and possess a spirit of perspective. In the opinion of [7], human beings are the only creatures who can embody their humanity because human beings are creatures who need education. The development of this human dimension is through the intellect that accompanies each dimension [8]. Covey talks about intelligence, which he refers to as an innate gift of each dimension, as intellectual intelligence, emotional intelligence, and spiritual intelligence. It is through the development of each of these kinds of intelligence that the human dimension undergoes development. Every effort to develop must have direction in order for the development to be meaningful for human beings and not be misdirected.

One way of initiating positive change in the tourism industry is through sustainable innovation, which is an integral aspect of social entrepreneurship. Social entrepreneurship can reduce economic disparity in a country if entrepreneurs work together closely with local communities. According to [9], social entrepreneurship should not only be oriented towards profit and or growth, but should also encourage an agenda for holistic development and focus on improving community welfare. Innovation is also extremely important for destinations that want to advance in a competitive tourism industry [10]. A destination will have a competitive advantage if the local tourism business follows a social entrepreneurship model that uses innovative strategies in connection with product and service offers, organizational structure, operational process, logistics, and marketing [11]. It is important to note that this competitive advantage, which is founded on innovation, should not only generate better financial profit but also provide social value [11].

In order for social entrepreneurship to build a competitive tourism industry, high selfefficacy is needed. According to Bandura, self-efficacy determines how people feel, think, motivate themselves, and behave [12]. Bandura explains about the effects and functions of self-efficacy in terms of the cognitive function, motivational function, affective function, and selective function. In entrepreneurship, self-efficacy is used as a benchmark for the possibility of an individual to start a business [13]. Entrepreneurial self-efficacy is shaped 
by taking into account two broader convictions, namely self-efficacy in learning and creative self-efficacy [14]. Self-efficacy can be used in understanding the creative actions of an individual [15].

The development of a destination is believed to evolve in six different phases, namely exploration, involvement, development, consolidation, stagnation, and decline or rejuvenation, each of which is marked by a number of identifiable features. The goal of tourism in the first stage is concerned with exploration and involvement, and this early stage is marked by only a small number of tourists. Special facilities are not yet available for visitors. Therefore, there is a high probability of using local facilities and engaging in contact with local residents, which in itself can present a significant attraction for some visitors [16]. The development of a destination is carried out to support the evolution desired by tourists, focussing solely on offers that provide an interesting experience, high quality infrastructure, and outstanding service in order to attract repeat visits [17]. Tourism is a broad phenomenon and it is important to consider the network of stakeholder relationships (networks), the strategic decision to expand business (competitiveness), the participation of organizational actors (governance) and the sustainable development of these systems (innovation and research). In tourism, innovation requires networks and systems of cooperation because companies are mutually dependent. In this way, territories have a primordial role $[18,19]$.

Research result has been done about local wisdom, conclude people in Thailand start studying collectively the problems in society are restore traditional local wisdom integrated with new knowledge [20]. Meanwhile in Romania, people rural areas realize that they have "treasures" in the form of each traditions, natural environment and how they are work. Through tourism in the form of geotourism, cultural tourism, agrotourism and traveling can be practiced successfully in Romania [21]. Although there are some local people whose involvement is low, but some have able to develop resource capitalization resources and promote tourism villages by holding a national tourism exhibition rural area. Research result in Bulgaria in the region mountain for tourism seen as a complex activity. Thing it involves additional activities such as production, services, transportation and education. Alternative tourism development in the mountain has a chance in solve problems in society such as unemployment, low income, economy narrow and backward business compared to lowland areas and big cities [22].

The purpose of this research is to carry out a detailed exploration of the development of a tourism village as a vehicle for integrating language education and local potential, to help build the image of a religious tourist destination in the world of tourism. This is an extremely important task because tourist destinations have in the past generally been associated with a life that is far removed from religion and local culture. It is therefore hoped that this research will propose the best practice for developing a religious tourism destination.

\section{Research Methods}

This research is a qualitative study with a descriptive method and was conducted in the Language Tourism Village in the Hamlet of Pakel, in the Karangpandan District of Karanganyar Regency. Qualitative research is research using a method of direct interviews to understand the attitudes and behavior of individuals and groups, in which open interviews are used to examine and understand the different points of view $[23,24]$. This method was chosen because the researcher wanted to describe accurately and systematically the forms of community empowerment, supported by the relevant facts.

The selection of the object for the research was related directly to the research focus. The object chosen for this research was the parties involved in the process of community 
empowerment. The study was conducted from April to September 2021. The informants selected by the researcher were the head of Pakel hamlet, the head of Isy Karima Islamic Boarding School, the head of the young people's Karang Taruna organization, and community representatives who participated in the empowerment process. Based on the selection of samples, the researcher chose to use a purposive sampling technique, in which the collection of samples used criteria determined by the researcher. This technique prioritizes samples of data and informants to explain the phenomena occurring, rather than using a population that is too large to expound the conditions relevant to the research [25], [26]. The selection of samples was decided based on criteria determined by the researcher, and included the head of Pakel hamlet as the person responsible for channelling information and directing the community; the head of Isy Karima Islamic Boarding School as the initiator of the innovation and the source of information for the idea of empowerment; the young people's organization (Karang Taruna); and community representatives who contributed to and participated in the village empowerment program. This criteria-based selection ensured that the informants were people who understood and knew about the operation of the community empowerment program through the language tourism village. Informants in this study were local communities (10 person), village officials ( 3 person), leaders of Isy Karimah Islamic boarding schools (3 person), head of tourism village development associations (1 person), the young people's organization (Karang Taruna) (5 person), souvenir craftsmen (7 person), local financial institutions ( 2 peson).

The data sources for the research included primary data and secondary data. The primary data was obtained through the primary source of individuals, and was acquired through in-depth interviews and observation [27,28]. The interview process for the research used a technique of data collection through face to face or direct interviews in order to obtain complete and in-depth information [29]. A semi-structured approach was used for the interviews so that the researcher could ask additional questions outside the guidelines in order to obtain data and information that was more comprehensive and detailed [30]. The researcher used a method of non-participant observation, visiting the field to seek information by observing the activities and interaction between individuals in the research location [26]. The researcher used the primary data source of observation and interviews together with secondary data collected from documents, books, journals, and photographic documentation. The next step was for the researcher to test the validity of the data using source triangulation. The triangulation of sources focuses on the researcher at the time of data collection by using a variety of data sources. Similar types of data can then be investigated in more depth along with a number of different data sources [31]. The data collected was presented in the form of sentences and a conclusion was then drawn using a technique of interactive analysis. According to [30, 32], this model of analysis is described by Miles and Huberman as the collection of data based on phenomena in the field, and the subsequent analysis using an interactive model. The three stages comprised in this data analysis were: data reduction, including the process of report writing based on the data collected, followed by the reduction of data to provide an illustration about the empowerment of the community in establishing a tourist destination; data presentation, by organizing the data in groups to facilitate the researcher's analysis; and conclusion, as the final result [33].

\section{Result and Discussion}

The presence of the Language Tourism Village in erdu Village, Karangpandan, is closely related to Isy Karima Islamic Boarding School. Language Tourism Village was established in 2017. The community empowerment in this village is one of the acts of service provided by the boarding school for the surrounding area. There was a calling to build a village that 
would become a tourist destination while at the same time contributing to the development of human civilization. In the beginning, the local community was given the opportunity to learn Arabic, English, and Japanese free of charge, at any time that was convenient, depending on whether they were free in the morning, afternoon, or evening. Those attending these free language tutorials ranged from children to elderly people living in the community around the boarding school. This confirms the statement that in community development, the education system must be provided by the developers themselves [34]. The attraction of tourist objects, not only lies in recreational or entertainment values. Educational and religious values have recently become the main attraction for most tours. Therefore, in good community development there is a need for education for the development itself. In Table 1, it can be seen that language education has an effect on spiritual intelligence, social entrepreneurship, and self-efficacy.

Table 1. Development of a tourism village based on language education

\begin{tabular}{|l|l|l|l|}
\hline $\begin{array}{c}\text { Language } \\
\text { Education }\end{array}$ & \multicolumn{1}{|c|}{ Aims and Objectives } & $\begin{array}{c}\text { Work mechanism and } \\
\text { design }\end{array}$ & \multicolumn{1}{|c|}{ Impact } \\
\hline Javanese & $\begin{array}{l}\text { Preserve a local } \\
\text { language that is suited to } \\
\text { local cultural values }\end{array}$ & $\begin{array}{l}\text { Provide education about } \\
\text { the Javanese language } \\
\text { that is suited to Javanese } \\
\text { cultural values as a } \\
\text { provision for life in the } \\
\text { community }\end{array}$ & $\begin{array}{l}\text { The community can apply the } \\
\text { Javanese language in a way } \\
\text { that is suited to Javanese } \\
\text { cultural norms (self-efficacy) }\end{array}$ \\
\hline English & $\begin{array}{l}\text { Introduce an } \\
\text { international language } \\
\text { to establish relations } \\
\text { between different } \\
\text { countries to build a } \\
\text { cooperative network }\end{array}$ & $\begin{array}{l}\text { Language training } \\
\text { applied to everyday } \\
\text { life with participants } \\
\text { sleeping in home } \\
\text { stays provided by the } \\
\text { local community }\end{array}$ & $\begin{array}{l}\text { The community can speak } \\
\text { English for the basic } \\
\text { purpose of establishing } \\
\text { social relations (social } \\
\text { entrepreneurship) }\end{array}$ \\
\hline Arabic & $\begin{array}{l}\text { Introduce the Arabic } \\
\text { language to gain } \\
\text { religious knowledge } \\
\text { that will serve as a } \\
\text { guide for the } \\
\text { community to help } \\
\text { them throughout their } \\
\text { lives }\end{array}$ & $\begin{array}{l}\text { Regular Arabic classes } \\
\text { every Monday, } \\
\text { Wednesday, and } \\
\text { Saturday, at Griya } \\
\text { Nabawi, in Pakel } \\
\text { Language Tourism } \\
\text { Village }\end{array}$ & $\begin{array}{l}\text { The community can } \\
\text { understand Arabic to aid } \\
\text { their religious study } \\
\text { (spiritual intelligence) }\end{array}$ \\
\hline
\end{tabular}

The spatial layout of the village relied on the awareness of each family, in accordance with the existing local potential and under the supervision of the educators from Isy Karima Islamic Boarding School. The community empowerment began with an analysis of the existing potential in the local community. The community was also centered on development, suggesting that community development is a process in which members of the same locality work together for shared goals [35]. Implementation of the National Program for Community Empowerment of Tourism Mandiri through Tourism Villages on the Development of Tourism Potential in Mandailing Natal Regency is implemented quite well, indicated by the empowerment of local young people in tourism management such as ticket guards, parking guards and cleaners, some of the village communities have opened businesses or sales at tourist attractions. [36]. The existing potential in the local community is shown in Table 2. Community involvement in a Tourism management is something that cannot be separated. After all, society is an element of development itself. 
Table 2. Development of a tourism village based on local potential

\begin{tabular}{|c|c|c|c|}
\hline Local Potential & $\begin{array}{c}\text { Program } \\
\text { developed }\end{array}$ & $\begin{array}{l}\text { Mechanism and } \\
\text { Design }\end{array}$ & Impact \\
\hline \multirow{2}{*}{$\begin{array}{l}\text { Panorama of } \\
\text { rice fields in a } \\
\text { beautiful } \\
\text { mountain } \\
\text { setting. } \\
\text { Location close } \\
\text { to the main } \\
\text { road. }\end{array}$} & $\begin{array}{l}\text { Opening a } \\
\text { restaurant in } \\
\text { the rice fields }\end{array}$ & $\begin{array}{l}\text { Synergizing the } \\
\text { potential of the land } \\
\text { with the skills of the } \\
\text { local community }\end{array}$ & $\begin{array}{l}\text { Many more employment } \\
\text { opportunities for the nearby } \\
\text { community. Acting as a magnet for } \\
\text { people to visit the tourism village. }\end{array}$ \\
\hline & $\begin{array}{l}\text { Developing } \\
\text { souvenirs } \\
\text { made from } \\
\text { local materials }\end{array}$ & $\begin{array}{l}\text { Combining local } \\
\text { potential with art to } \\
\text { develop the creative } \\
\text { economy }\end{array}$ & $\begin{array}{l}\text { The community can utilize existing } \\
\text { local potential to make souvenirs for } \\
\text { visitors who come to the tourism } \\
\text { village. }\end{array}$ \\
\hline $\begin{array}{l}\text { Many people } \\
\text { have good } \\
\text { culinary skills. }\end{array}$ & $\begin{array}{l}\text { Opening } \\
\text { places to make } \\
\text { clothes }\end{array}$ & Teaching life skills & $\begin{array}{l}\text { The community is more productive. } \\
\text { People can have clothes made } \\
\text { locally. More local job } \\
\text { opportunities. }\end{array}$ \\
\hline $\begin{array}{l}\text { culinary skills. } \\
\text { Many people } \\
\text { are skilled } \\
\text { livestock } \\
\text { farmers. }\end{array}$ & $\begin{array}{l}\text { Developing } \\
\text { livestock } \\
\text { farming }\end{array}$ & $\begin{array}{l}\text { Teaching livestock } \\
\text { farming skills and } \\
\text { establishing cooperative } \\
\text { networks and } \\
\text { partnerships }\end{array}$ & $\begin{array}{l}\text { The community can rear livestock } \\
\text { and earn a living to support their } \\
\text { lives. People can form business } \\
\text { relations. }\end{array}$ \\
\hline
\end{tabular}

Table 3. Integration of language education and local potential

\begin{tabular}{|l|l|}
\hline Characterization & \multicolumn{1}{c|}{ Impact } \\
\hline Internal skills & $\begin{array}{l}\text { By learning to understanding the Arabic language, the local community and } \\
\text { visitors to the tourism village can increase their religious knowledge, beneficial } \\
\text { for their lives. } \\
\text { People understand that business is not only for the self interests of the } \\
\text { individual, but instead they develop a spiritual vision and the ability to take } \\
\text { wisdom from suffering. }\end{array}$ \\
\hline External skills & $\begin{array}{l}\text { Stronger mutual cooperation and togetherness in developing existing local } \\
\text { potential, marked by collective business management. } \\
\text { Land that in the past was unproductive is now utilized by the community and } \\
\text { has been turned into productive land for the common good. }\end{array}$ \\
\hline Orientation & $\begin{array}{l}\text { People understand that business is not only for the interests of the individual } \\
\text { but also for the benefit of the community in order for them all to achieve } \\
\text { mutual prosperity. } \\
\text { People are aware that business is not only focused on profit alone but also } \\
\text { takes into consideration the surrounding environment, for example by } \\
\text { preserving the environment and improving the welfare of the local }\end{array}$ \\
\hline $\begin{array}{c}\text { Capital } \\
\text { Cognitive } \\
\text { function }\end{array}$ & $\begin{array}{l}\text { People are aware that money is not the primary element of capital but instead, it } \\
\text { is the values of social capital that determine success in business. }\end{array}$ \\
\hline $\begin{array}{l}\text { Motivational } \\
\text { function }\end{array}$ & $\begin{array}{l}\text { People are aware of the local potential that exists nearby and can be managed to } \\
\text { bring added value. For example, bamboo, which in the past has been used only } \\
\text { for kitchen equipment, is now used for making various kinds of souvenirs with }\end{array}$ \\
\hline $\begin{array}{l}\text { Affective } \\
\text { function }\end{array}$ & $\begin{array}{l}\text { People develop a passion for business, utilizing the local potential that exists } \\
\text { nearby, marked by an increase in the numbers of young people setting up new }\end{array}$ \\
\hline $\begin{array}{c}\text { Selective } \\
\text { function }\end{array}$ & $\begin{array}{l}\text { People feel that their lives are comfortable, calm, and free from anxiety or } \\
\text { depression despite the difficulties in the current economic situation, because }\end{array}$ \\
\hline
\end{tabular}

The Islamic boarding school has integrated language (culture) with the existing local potential in the local community. Table 3 shows that spiritual intelligence, social 
entrepreneurship, and self-efficacy are all factors that determine success in developing the local economy. In this research, these three entities are proven to have the capacity to inspire the local community and have a very wide impact on community development in the local area

Table 4. Supporting facilities and media for building religious values

\begin{tabular}{|c|c|c|c|}
\hline \multirow{2}{*}{$\begin{array}{l}\text { Entity of } \\
\text { Religious } \\
\text { Tourism } \\
\text { Village }\end{array}$} & \multirow[t]{2}{*}{ Use } & \multicolumn{2}{|c|}{ Dimensions and Religious Values Developed } \\
\hline & & Dimension & Religious Value \\
\hline \multirow{3}{*}{$\begin{array}{l}\text { Rumah } \\
\text { Nabawi } \\
\text { (house like } \\
\text { in } \\
\text { Madinah) }\end{array}$} & \multirow{3}{*}{$\begin{array}{l}\text { A place where } \\
\text { visitors can stay to } \\
\text { gain religious } \\
\text { knowledge, and a } \\
\text { place for } \\
\text { introducing a } \\
\text { religious way of life } \\
\text { to the community }\end{array}$} & $\begin{array}{l}\text { Relationship } \\
\text { between human } \\
\text { beings and God }\end{array}$ & $\begin{array}{l}\text { People get to know a living place that is } \\
\text { consistent with religious teachings, and } \\
\text { promotes a healthy lifestyle with every } \\
\text { effort to practice good habits }\end{array}$ \\
\hline & & $\begin{array}{l}\text { Relationship } \\
\text { between human } \\
\text { beings }\end{array}$ & $\begin{array}{l}\text { Builds an attitude of compliance and } \\
\text { obedience to rules related to the } \\
\text { community and public interest }\end{array}$ \\
\hline & & $\begin{array}{l}\text { Relationship } \\
\text { between human } \\
\text { beings and the } \\
\text { environment }\end{array}$ & $\begin{array}{l}\text { Builds an attitude or behavior that always } \\
\text { tries to prevent damage to the surrounding } \\
\text { natural environment. }\end{array}$ \\
\hline \multirow[t]{3}{*}{$\begin{array}{l}\text { Meeting } \\
\text { hall }\end{array}$} & \multirow{3}{*}{$\begin{array}{l}\text { A place where } \\
\text { people can recite the } \\
\text { Qur'an, study } \\
\text { religion, and hold } \\
\text { discussions }\end{array}$} & $\begin{array}{l}\text { Relationship } \\
\text { between human } \\
\text { beings and God }\end{array}$ & $\begin{array}{l}\text { Instills a religious way of life that } \\
\text { encourages people to learn }\end{array}$ \\
\hline & & $\begin{array}{l}\text { Relationship } \\
\text { between human } \\
\text { beings }\end{array}$ & $\begin{array}{l}\text { Builds an attitude and behavior that } \\
\text { encourages people to produce something } \\
\text { useful for the community and recognize } \\
\text { and respect the success of others }\end{array}$ \\
\hline & & $\begin{array}{l}\text { Relationship } \\
\text { between human } \\
\text { beings and the } \\
\text { environment }\end{array}$ & $\begin{array}{l}\text { Builds a sense of concern for the } \\
\text { environment from an early age and fosters } \\
\text { children's creativity so that they are able } \\
\text { to develop the potential of their } \\
\text { surrounding environment }\end{array}$ \\
\hline \multirow{3}{*}{$\begin{array}{l}\text { Camping } \\
\text { ground and } \\
\text { Gazebo } \\
\text { with a tree } \\
\text { house }\end{array}$} & \multirow{3}{*}{$\begin{array}{l}\text { A place where } \\
\text { people can stay for a } \\
\text { few days with } \\
\text { family or colleagues } \\
\text { who belong to the } \\
\text { same organization } \\
\text { or association to } \\
\text { form connections } \\
\text { between families }\end{array}$} & $\begin{array}{l}\text { Relationship } \\
\text { between human } \\
\text { beings and God }\end{array}$ & $\begin{array}{l}\text { Brings people closer to God through } \\
\text { admiration for all God's creations that } \\
\text { surround them }\end{array}$ \\
\hline & & $\begin{array}{l}\text { Relationship } \\
\text { between human } \\
\text { beings }\end{array}$ & $\begin{array}{l}\text { Builds humanistic relations, togetherness, } \\
\text { and mutual cooperation between people, } \\
\text { and instills a sense of independence for } \\
\text { people to live their lives }\end{array}$ \\
\hline & & $\begin{array}{l}\text { Relationship } \\
\text { between human } \\
\text { beings and the } \\
\text { environment }\end{array}$ & $\begin{array}{l}\text { Raises awareness about the carrying } \\
\text { capacity of natural and environmental } \\
\text { potential for people's lives, promotes good } \\
\text { hygiene, service, and forward thinking }\end{array}$ \\
\hline \multirow[t]{3}{*}{$\begin{array}{l}\text { Horse } \\
\text { riding } \\
\text { tourist spot }\end{array}$} & \multirow{3}{*}{$\begin{array}{l}\text { Facilitates access to } \\
\text { horse riding, which } \\
\text { is generally } \\
\text { regarded as a sport } \\
\text { for the middle and } \\
\text { upper classes, so } \\
\text { that it can be } \\
\text { enjoyed by anyone, } \\
\text { because horse riding } \\
\text { was also a habitual } \\
\text { practice (Sunnah) of } \\
\text { the Prophet }\end{array}$} & $\begin{array}{l}\text { Relationship } \\
\text { between human } \\
\text { beings and God }\end{array}$ & $\begin{array}{l}\text { Strengthens faith in God, that people were } \\
\text { created as caliphs in this world, to } \\
\text { optimize all that exists in the world and } \\
\text { lead a life that follows the Sunnah of the } \\
\text { Prophet Muhammad }\end{array}$ \\
\hline & & $\begin{array}{l}\text { Relationship } \\
\text { between human } \\
\text { beings }\end{array}$ & $\begin{array}{l}\text { Builds cooperation, encouraging people to } \\
\text { share knowledge, as well as helping to } \\
\text { build the local economy }\end{array}$ \\
\hline & & $\begin{array}{l}\text { Relationship } \\
\text { between human } \\
\text { beings and the } \\
\text { environment }\end{array}$ & $\begin{array}{l}\text { Raises awareness about harmonious } \\
\text { relationships with all God's creations }\end{array}$ \\
\hline
\end{tabular}


Various supporting facilities and media have been built to integrate these two aspects. The purpose of building these facilities and media is to facilitate visitors to the tourism village and to serve as a vehicle for developing human civilization and increasing religious values. However, in the management of this community-based tourism, the role of local people is prioritized, because the main objective is the welfare of the local community through economic improvement by utilizing the existing potential [37], The various entities of the Language Tourism Village are shown in the Table 4.

The Village Government and Isy Karima Islamic Boarding School are the two main parties that have worked on the development of the Language Tourism Village, each in accordance with its own role. The village government coordinated with the district government to obtain funding from the local government budget (APBD), the main target of development being the road infrastructure. In 2019, the village government obtained IDR 100 million from the APBD funds for paving the roads, IDR 75 million for building retaining walls, and IDR 30 million for reinforcing the roads with concrete slabs and other uses. The village government also received the facilities and opportunity to carry out a comparative study in the city of Malang to learn about tourism management. In 2020, the village government expanded the development of its tourism potential to surrounding areas, developing the creative economy by establishing centers for growing eggplants and bamboo handicrafts. This is in line with [38], who explains that the practice of community development can overcome problems and meet needs by improving relationships between members of the community, fostering togetherness, and encouraging enthusiasm for empowering local potential. Hence, the model for community empowerment is different in every area, because every village has its own unique characteristics and local potential [38], [39], [40].

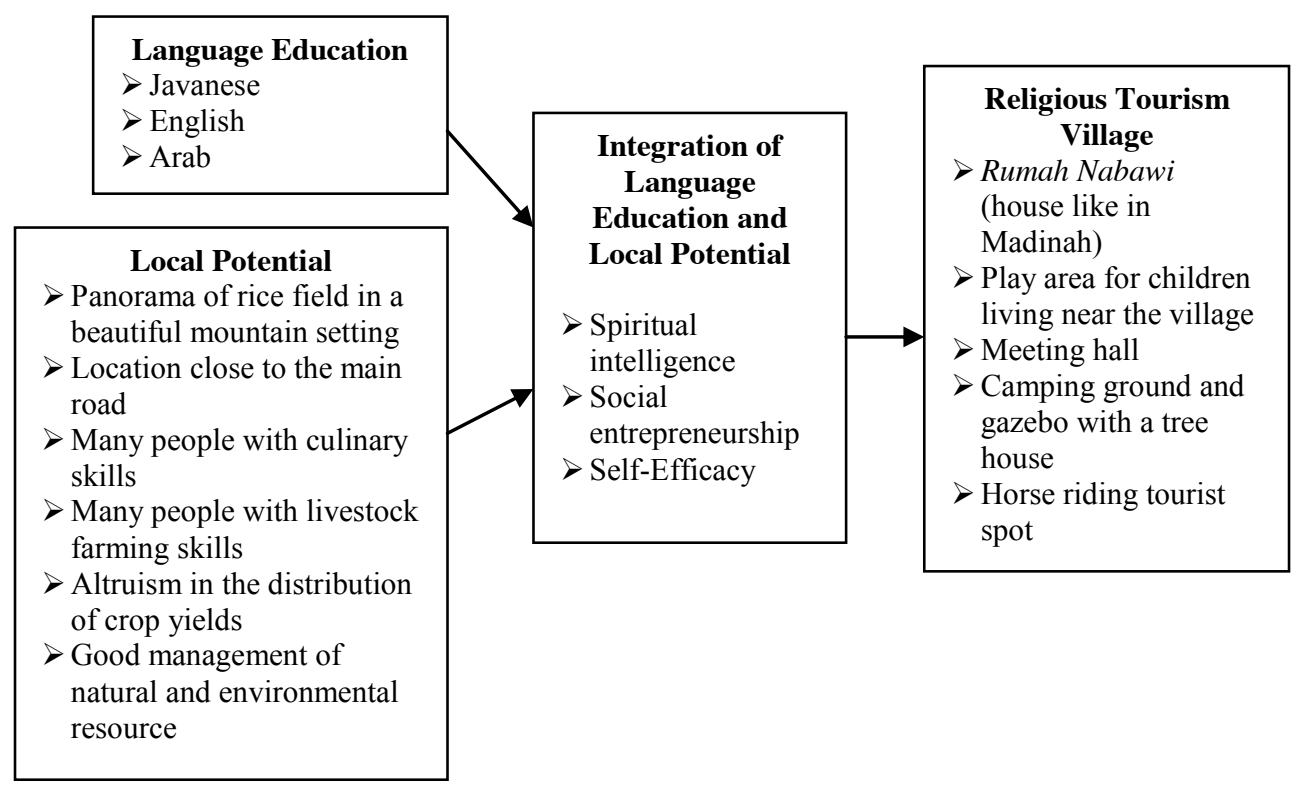

Fig. 1. Model of Development of a Tourism Village Based on the Integration of Language Education and Local Potential

Furthermore, visitors and or people who go to the Language Tourism Village to learn are encouraged to shop for souvenirs produced by the local residents. The village government has made further expansions by building roads leading home that pass through nearby villages, where residents who were previously only spectators are now able to enter into the tourism circle. Efforts to develop an 'Eggplant Village' and bamboo handicraft 
center have been underway since 2019 . The village government has also prepared a selfie spot and 5,000 square meters of land belonging to the village treasury that has been planted with durian and avocado trees. The seedlings were donated by the Solo Watershed Management Office (BPDAS). Management plans will subsequently be left up to Village Owned Enterprises. The impact of tourism village development on the welfare of the community is the increasing number of creative economy business actors, decreasing the rate of urbanization, absorbing local workers. all of this has an impact on increasing the purchasing power and income of local communities. The diagram below shows the model for a religious tourism village based on integration between language education and local potential.

\section{Conclusion}

The Language Tourism Village in Karanganyar Regency has succeeded in establishing a religious tourism village based on language education and local potential. The existence of this religious tourism village can set an example to show the best practice for changing the negative image of tourism to become more positive. Tourist sites, which are usually viewed in a negative light, will thus see a positive change and become associated with religious and cultural values.

\section{References}

1. Dodds, R., Ali, A., \& Galaski, K. 2016. Mobilizing knowledge: Determining key elements for success and pitfalls in developing community-based tourism. Current Issues in Tourism.

2. Freire, Paulo. 2005. Education for Critical Consciousness.London-New York: Continuum.

3. Bruns, H., Kantorowicz-Reznichenko, E., Klement, K., Jonsson, M. L., \& Rahali, B. 2018. Can nudges be transparent and yet effective? Journal of Economic Psychology, 65, 41-59.

4. Bhuiyan, M. A. H., Siwar, C., \& Ismail, S. M. 2013. Tourism development in Malaysia from the perspective of development plans. Asian Social Science, 9(9), 11.

5. Daniele, R., \& Quezada, I. (2017). Business models for social entrepreneurship in tourism. In P. J. Sheldon, \& R. Daniele (Eds.). Social entrepreneurship and tourism: Philosophy and practice. 81-100.

6. Dewey, J. (1963). Freedom and Culture. USA: Capricorn Books Edition.

7. Tilaar, H. A. (2012). R, dan Riant Nugroho. Kebijakan Pendidikan: Pengantar untuk Memahami Kebijakan Pendidikan dan Kebijakan Pendidikan sebagai Kebijakan Publik. Yogyakarta: Pustaka Pelajar.p 22-23

8. Covey, S. R. (2013). The 8th habit: From effectiveness to greatness. Simon and Schuster.

9. Fortunato, M. W. P., \& Alter, T. 2015. Community entrepreneurship development: An introduction. Community Development. Vol 46(5): 444-455.

10. Quandt, C., Ferraresi, A., Kudlawicz, C., Martins, J., \& Machado, A. (2017). Social innovation practices in the regional tourism industry: Case study of a cooperative in Brazil. Social Enterprise Journal. Vol 13(1): 78-94 
11. Aquino, R. S., Lück, M., \& Schänzel, H. A. (2018). A conceptual framework of tourism social entrepreneurship for sustainable community development. Journal of Hospitality and Tourism Management, 37, 23-32.

12. Bandura, A. 2002. Self efficacy: The exercise of control. NY: W. H. Freeman \& Company.

13. Abdullah, S. M. (2019). Social cognitive theory: A Bandura thought review published in 1982-2012. Psikodimensia, 18(1), 85-100.

14. Fuller, B., Liu, Y, Bajaba, S., Marler, E.L., \& Pratt, J. (2018). Examining How The Personality, Self-efficacy, and Anticipatory Cognitions of Potential Entrepreneurs Shape Their Entrepreneurial Intentions. Personality and Individual Differences, 125,120-125.

15. Puente-Díaz, R. (2016). Creative self-efficacy: An exploration of its antecedents, consequences, and applied implications. The Journal of psychology, 150(2), 175-195.

16. Hussin, N. Z. 2019. Tracing the Malaysia Tourism Lifecycle and Strategy Assessment from the First Malaysia Plan to Ninth Malaysia Plan. International Journal of Business and Social Science. Vol 5(3): 161-168.

17. Abdillah, F., Leewellyn, V., \& Yadisaputra, M. 2020. Local Community Life Satisfaction at Early Stage Tourist Destination. E-Journal of Tourism. Vol 7(2): 177192.

18. Folgado-Fernández, J. A., Di-Clemente, E., Hernández-Mogollón, J. M., \& CampónCerro, A. M. (2019). Water tourism: A new strategy for the sustainable management of water-based ecosystems and landscapes in Extremadura (Spain). Land, 8(1), 2.

19. Brandão, F., Breda, Z., \& Costa, C. (2019). Innovation and internationalization as development strategies for coastal tourism destinations: The role of organizational networks. Journal of Hospitality and Tourism Management, 41, 219-230.

20. Mungmachon, M. R. (2012). Knowledge and local wisdom: Community treasure. International Journal of Humanities and Social Science, 2(13), 174-181.

21. Dorobantu, M. R., Gheorghe, G., \& Nistoreanu, P. (2012). New ways to value tourism resources from rural environment. in competitiveness of agro economy. In Food and Environmental (pp. 385-394). Bucharest: Faculty of Agro-Food and Environmental Economics, University of Economic Studies. Retrieved from https://www.researchgate.net/publication/237148452_New_ways_to_value_tourism_r esources_from_rural_environment.

22. Patarchanov, P. (2012). Role and place of alternative tourism development in mountain areas. Journal of Settlements and Spatial Planning, 1(1), 149-155. Retrieved from http://jssp.reviste.ubbcluj.ro

23. Moleong, L. J. (2019). Metodologi penelitian kualitatif.

24. Putri, V., Yukihana, A., Shafira, A., Tasya, A., \& Al-Aufa, B. (2019). The entrepreneurship capacity building program and empowering fisherwomen Sawohan Village, East Java. ASEAN Journal of Community Engagement, 3(2), 4.

25. Yin, R. K. (2011). Applications of case study research. Sage.

26. Arofah, L. (2017, November). Relation Between Multicultural Education, Sociology, and Indigenous Knowledge. In 1st International Conference on Social Sciences Education-" Multicultural Transformation in Education, Social Sciences and Wetland Environment"(ICSSE 2017) (pp. 188-192). Atlantis Press.

27. Daymon, Christine and Holloway, Immy. 2008. Metode Riset Kualitatif dalam Public Relations dan Marketing Communications. Yogyakarta: Penerbit Bentang 4. 
28. Sutopo, H. B. Metodologi Penelitian Kualitatif, dasar Teori dan Terapannya Dalam Penelitian. 2002. Surakarta: UNS.

29. Creswell, J. W., \& Poth, C. N. (2016). Qualitative inquiry and research design: Choosing among five approaches. Sage publications.

30. Anggito, A., \& Setiawan, J. (2018). Metodologi penelitian kualitatif. CV Jejak (Jejak Publisher).

31. Patton, M. Q. (2014). Qualitative research \& evaluation methods: Integrating theory and practice. Sage publications.

32. Miles, Matthew. B dan Huberman, A. Michael., 1992. Analisis Data Kualitatif. (Terj. Tjetjep Rohendi Rohidi). Jakarta: Universitas Indonesia.

33. Pujileksono, S. (2015). Metode penelitian komunikasi kualitatif. Malang: Intrans Publishing.

34. Saepudin, A., \& Mulyono, D.2019. Community education in community development. EMPOWERMENT: Jurnal Ilmiah Program Studi Pendidikan Luar Sekolah. Vol 8(1): 65-73.

35. Porter, B. A., Orams, M. B., \& Lück, M. 2018. Sustainable entrepreneurship tourism: An alternative development approach for remote coastal communities where awareness of tourism is low. Tourism Planning \& Development. Vol 15(2): 149-165.

36. Lubis, F. S. (2021). Implementasi Kebijakan PNPM Mandiri Pariwisata Melalui Desa Wisata Terhadap Pengembangan Potensi Pariwisata di Kabupaten Mandailing Natal (Doctoral dissertation).

37. Muhammad, F. (2017). Pesona Kearifan Lokal Sebagai Wahana Peningkatan Produktifitas Ekonomi Masyarakat. Jurnal Pemberdayaan Masyarakat: Media Pemikiran dan Dakwah Pembangunan, 1(2), 275-294.

38. Mtika, M.M. and M. Kistler. 2017. Contiguous community development. Journal of Rural Studies 5 (1): 83-92.

39. Kenneth, E. P. 2017. Three Faces of Empowerment: Expanding the Theory of Empowerment in Community Development. Journal of the Community Development Society, 33(1): 107-123.

40. Noruzi MR, Westover JH dan Gholam RR. 2018. An Exploration of social entrepreneurship in the entrepreneurhip era. J of Asian Social Science 6(6): 151-67. 